\title{
The Statue of Mery "the High Priest of Amun" in the Egyptian Museum, Cairo CG 973
}

\author{
Dina El Gabry \\ Faculty of Tourism and Hotel Management, Helwan University
}

\begin{abstract}
This article publishes the fragmentary statue of Mery (CG 973), which is now conserved in the basement of the Egyptian Museum in Cairo. Mery was a high priest of Amun hm-ntr tpy $n$ 'Imn, who lived and served during the reign of Amenhotep II. The majority of his titles are related to the administration of Amun's estates. Several sources are helpful in gathering information about Mery who was considered a very important person due to his ranking in the royal administration. Many scholars have discussed Mery's tomb TT 95 at Sheikh Abd el-Qurna, along with TT 84, which he usurped. Two funerary cones were also attributed to Mery. However, no scholar has published Mery's statue before; only the titles preserved on it have been mentioned. For these reasons, I found it significant to closely study and examine this valuable piece to shed light on the monument of one of the most distinctive high priests in the Eighteenth Dynasty.
\end{abstract}

\section{Description (fig. 1)}

This seated statue is made of black granite. ${ }^{1}$ Nothing is known about the statue's provenance. It is $33 \mathrm{~cm}$ in height, $14.5 \mathrm{~cm}$ in width and $23.5 \mathrm{~cm}$ in depth. It is in a bad state of preservation judging by the completely missing upper part of the statue, along with the base and the feet.

It seems that Mery is wearing a long kilt upon which few inscriptions are still visible. The inscriptions on the two sides of the seat are better preserved compared to those of the kilt. Even though few of the words are missing on the seat's sides, what remains of the texts are of high quality and deserve a

\footnotetext{
${ }^{1}$ CG 973, SR 8V/54 (Special Register). A special thank you is dedicated to Mrs. Sabbah Abd El Raziq, the director of the Egyptian Museum in Cairo, and Mrs. Azza, the curator in charge of the collections in the basement of the Egyptian Museum, for allowing me to study and photograph the piece. I would like to express my gratitude to Prof. Karl Jansen-Winkeln for his valuable comments and for helping me in identifying some hieroglyphic words. I am also grateful to my friend Dr. Elizabeth Waraksa for her relevant comments on the article. For the statue, see L. Borchardt, Statuen und Statuetten von Königen und Privatleuten im Museum von Kairo. Teil 4. Text und Tafeln zu Nr. 951-1294, CGC (Berlin,1934), 9-10 (text). Ranke mentions several orthographies for the name of Mery, for this see Ranke, PN I, 160, no. 1.
} 


\section{The Statue of Mery "the High Priest of Amun" in the Egyptian Museum, Cairo CG 973}

closer examination. The back of the statue is plain with no decoration or inscriptions on it. The hieroglyphic inscriptions on the sides mention several deities such as Amun, Hathor, and the Ennead.

\section{The Inscriptions}

The inscriptions on the kilt of Mery can be read as (figs. 2-4):

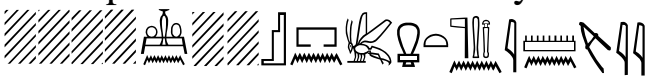

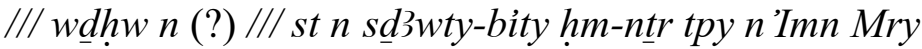

/// Offering table of /// place, to/of the seal-bearer of the king of Lower Egypt, the high priest of Amun, Mery.

The inscriptions on the right side of the statue can be read as (figs. 5-6):

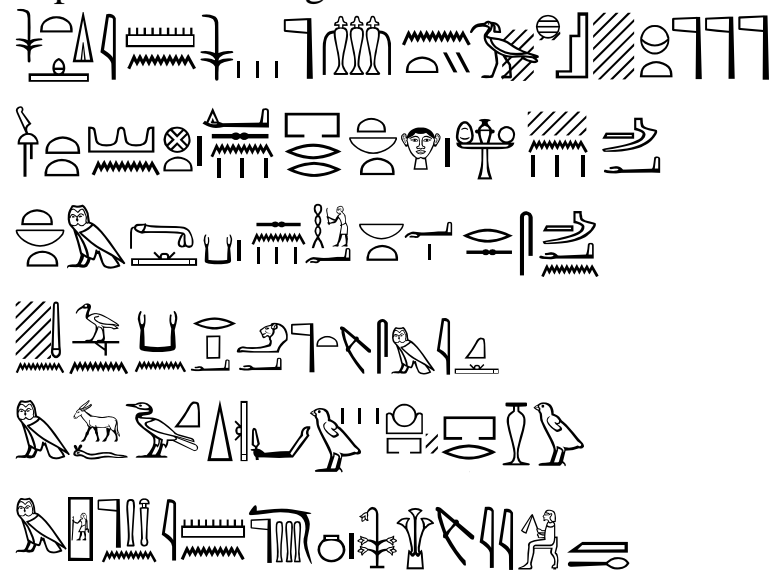

htp di nsw'Imn nsw ntrw hnty $3 h$-s $s(t) p s \underline{d} t$

imntt n niwt di.sn prrt nbt hr wdhw. (s)n $m 3^{\mathrm{C}} \mathrm{t}$

$n b t$ m-b3h k3.sn hwi nbt ${ }^{\mathrm{C}}$ r.s $s m 3^{\mathrm{c}^{2}} \mathrm{n}$

// mdw n Dhwty n k3 n iry-pet h3ty it-ntr mry-ntr ${ }^{3}{ }^{\top} m^{4}$ iqr

$m s^{c} h . f^{5}{ }^{c} q \operatorname{spd}(w)^{6} D s r w-3 h t^{7}$ pri hs $(w)$

\footnotetext{
${ }^{2}$ WB IV, 124-125.

${ }^{3}$ For it-ntr mry-ntr, see $W B$ I, 142 (6).

${ }^{4}$ R. Hannig, Ägyptisches Wörterbuch II. Mittleres Reich und Zweite Zwischenzeit, KAW 112, 2 vols. (Mainz am Rhein, 2006), 2: 2195.

${ }^{5}$ Hannig, Ägyptisches Wörterbuch II, 2: 2112-2113, esp. 2113.

${ }^{6}$ For the meaning of $s p d$ as 'to be happy,' see WB IV, 109 (8-10). For the main meaning of spd as 'to be pointed/sharp, effective, clever,' see Hannig, Ägyptisches Wörterbuch II, 2: 2183-2184.
} 


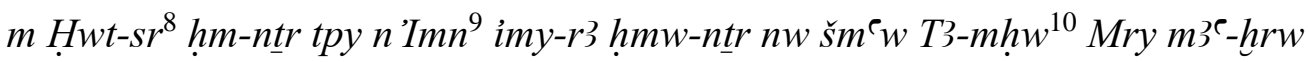

An offering which the king gives (to) Amun, the king of the gods, who is in front of the glorious place, ${ }^{\mathrm{A}}$ (and to) the Ennead of the West of the city, so that they may give all that come forth from their offering-tables, ${ }^{\mathrm{B}}$ all the truth before their Ka, all against which the arm strikes (all that is consecrated, which means the offering), ${ }^{\mathrm{C}}$ the ones who set right (the judgment) of Thoth ${ }^{\mathrm{D}}$ for the Ka of the hereditary prince, the mayor, the god's father, the beloved of the god, the excellent Sem priest in his rank, ${ }^{\mathrm{E}}$ the one who enters joyfully $\underline{D} s r w$-3ht and the one who comes out praised from $H w t-s r$, the high priest of Amun, and the overseer of the priests of Upper and Lower Egypt, Mery, the justified.

\section{Textual Remarks}

A- According to Gauthier, 3h-st is one of many epithets for the Karnak temple of Amun. ${ }^{11}$ The space following the seat sign [ is supposed to be filled with the $t$ sign and the house determinative to form the word $s t$.

B- The space after the offering table should be reconstructed with an $s$ as a part of the plural suffix pronoun $s n$.

C- hwi nbt ': the main entry of verb hwi is 'to strike, beat, smite, hit,' whereas the expression $h w i{ }^{\circ} r$ means 'extending the arm to dedicate an offering' which certainly indicates the consecration of offerings. ${ }^{12}$ Based on Meeks' translation, it means "frapper une offrande pour la consacrer." ${ }^{\prime 3}$ Therefore, $h w t n b t^{c} r$ should be understood as 'all against

\footnotetext{
7 According to Gauthier, Dsrw 3ht means 'august/glorious of horizon,' see H. Gauthier, Dictionnaire des noms géographiques contenus dans les textes hiéroglyphiques, vol. 6 (Le Caire, 1929), 132; Urk. IV, 1459 (5, 9).

${ }^{8}$ For Hwt-sr, see Hannig, Ägyptisches Wörterbuch II, 2: 1636; WB IV, 189 (8): 'the princely house (in Heliopolis) as a place where the gods held court;' D. Meeks, Année Lexicographique: Égypte Ancienne III (Paris, 1982), 182, no. 79.1860; L. Manniche, Lost Tombs. A Study of Certain Eighteenth Dynasty Monuments in the Theban Necropolis (London-New York, 1988), 94, 96 (Tomb of Simut: TT A24).

${ }^{9}$ A. Al-Ayedi, Index of Egyptian Administrative, Religious and Military Titles of the New Kingdom (Ismailia, 2006), 345-346, no. 1171.

${ }^{10} \mathrm{Al}-\mathrm{Ayedi}$, Index, 83-84, no. 271.

${ }^{11} \mathrm{H}$. Gauthier, Dictionnaire des noms géographiques contenus dans les textes hiéroglyphiques, vol. 1 (Le Caire, 1925), 10.

${ }^{12}$ WB III, 47 (2-3); Hannig, Ägyptisches Wörterbuch II, 2: 1624-1627, esp. 1626.

${ }^{13}$ D. Meeks, Année Lexicographique: Égypte Ancienne I (Paris, 1980), 240, no. 77. 2623. For the meaning of $h w t^{\text {' }} r$ as 'to consecrate,' see A. M. Blackman, "On the Position of Women in the Ancient Egyptian Hierarchy," JEA 7, no. 1/2 (Apr. 1921), 8-30, esp. 20, 25.
} 


\section{The Statue of Mery "the High Priest of Amun" in the Egyptian Museum, Cairo CG 973}

which the arm strikes, i.e all that is consecrated when offerings are made to the god Thoth.' The main difficulty in this sentence is the position of $n b t$ after the verb, but there is a clear parallelism between this sentence and those that precede it: $m 3^{\top} t n b t$ and $h w i n b t$. That is why, I prefer to translate both of them as 'all.'

D- This part of the text is problematic and vague. At the beginning of the fourth line, Borchardt wrote it as $\mathrm{l}$; however, I do not agree with Borchardt's restoration because the first sign to the left, which he considered as an elongated stroke, is not clear at all; also the short stroke is not correct. ${ }^{14}$ In my opinion, the short stroke seems like 'a staff' that can be read as $m d w$. Based on that, I suggest to fill this lacuna with $w d{ }^{\prime}$ $m d w$ (lit.: the one who divides the words or the divider of the words). ${ }^{15}$ As stated in the $W B$, the expression $w d^{2}-m d w$ means 'judging (of the king, of Thoth and other deities or officials). ${ }^{16}$ According to Hannig, $s m 3^{c} n w d^{\top}-m d w$ means 'the regulator of judicial judgments/decisions. ${ }^{17}$ In this case, $s m{ }^{3}$ is an active participle, referring to the Ennead who played an essential role in the judgment.

For the different writings of $h w$, see A. H. Gardiner, "The Hieratic Writing of the Verb $h w$ «to strike»," ZÄS 44 (1907), 126-129.

${ }^{14}$ Borchardt, Statuen und Statuetten, 10.

${ }^{15}$ In this case $w d^{c}$ is an active participle and $m d w$ is the object of the participle. See S. Lippert, "Law Courts," in W. Wendrich et al., eds., UCLA Encyclopedia of Egyptology (Los Angeles, 2012), 1-26, esp. 2-3 https://escholarship.org/uc/item/4136j3s7. See also D. Meeks, Année Lexicographique: Égypte Ancienne II (Paris: 1981), 113, no. 78. 1177; N. Strudwick, The Administration of Egypt in the Old Kingdom: The Highest Titles and their Holders, StudEgypt (London-Boston, 1985), 195-196 (sm3e wd ${ }^{\top}-m d w n$ Hwt wrt); E. Brovarski, "Hwt, Hwt wrt, and Hwt- 'nh," Études et Travaux 26/1 (2013), 143-151, esp. 149. ${ }^{16}$ WB I, 405 (10-14); Urk. IV, 1074 (13).

17 Another translation of $s m 3^{\top} n w \underline{d}^{\top}-m d w n$ Dhwty could be "what has become right by the order/decree of Thoth." In this case, $s m 3$ ' would be a passive participle, not an active participle. For $s m 3^{\complement} n$ w $\underline{d}^{\complement}-m d w$, see R. Hannig, Großes Handwörterbuch Ägyptisch-Deutsch (2800-950 v. Chr.): die Sprache der Pharaonen, KAW 64 (Mainz am Rhein, 2006), 761. For sm3`, see Hannig, Ägyptisches Wörterbuch II, 2: 2205-2206. For $w \underline{d}^{\top}-m d w$, see Hannig, Ägyptisches Wörterbuch II, 1: 771-772. See also D. Jones, An Index of Ancient Egyptian Titles, Epithets and Phrases of the Old Kingdom, BAR-IS 866 II, vol. 2 (Oxford, 2000), 889-890, no. 3256. Jones translates the epithet $s m 3^{\complement}(n) w d^{\top}-m d w$ as "one who sets right the judgment;" Al-Ayedi, Index, 264, no. 913. 
E- For parallels of $m s^{c} h . f$, see the inscriptions of Iamunedjeh, which provide us with assorted examples in which the word $s^{c} h$ is written in this same form. ${ }^{18}$

The inscriptions on the left side of the statue can be read as (figs. 7-8):

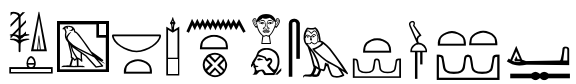

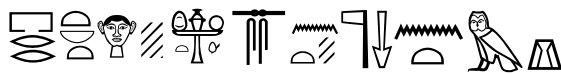

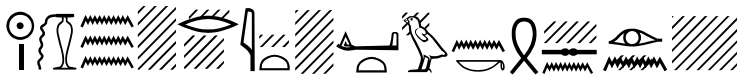

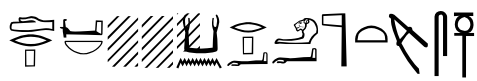

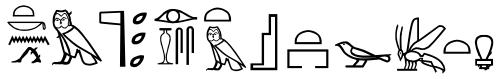

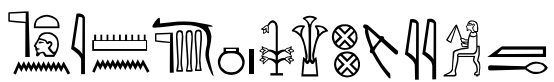

htp di nsw Hwt-Hr nbt'Iwnt hr-tp smyt imntt di.s

prrt nbt hr /// wdihw.s ssnt sntr $m$ hrt-

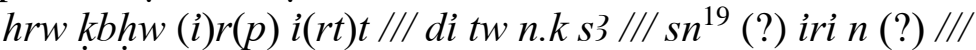

$d r p^{20} n b / / / k 3 n$ iry-pet h3tye it-ntr mry-ntr smr

tkn $m$ hִw-ntr iri hsst $m$ st-wr(t) sdiswty-bity

it-ntr tpy n'Imn imy-r了 hmw-ntr nw šm ${ }^{`} w$ T3-mhw Mry m3`-hrw

An offering which the king gives (to) Hathor, the lady of Dendara, who is upon the Western necropolis, so that she may give all that come forth from her offering-tables to smell ${ }^{\mathrm{F}}$ incense daily, cool water, wine and milk ${ }^{\mathrm{G}}$ that their (?) protection is given to you ${ }^{\mathrm{H}}$ /II All that is offered /// (for) the Ka of the hereditary prince, the mayor, the god's father, the beloved of the god, the friend, who approaches the divine body (namely; the king), ${ }^{\mathrm{I}}$ who makes praises in the great place, ${ }^{\mathrm{J}}$ the seal-bearer of the king of Lower Egypt, the chief god's father of Amun, and the overseer of the priests of Upper and Lower Egypt, Mery, the justified.

\footnotetext{
${ }^{18}$ For parallels, see Urk. IV, 957 (17), 961 (11). For a discussion of $m s h$, see D. M. Doxey, Egyptian Non-Royal Epithets in the Middle Kingdom: A Social and Historical Analysis, PdÄ 12 (Leiden-Boston, 1998), 163, 167.

${ }^{19}$ I think in this case it will be $s \underline{d m}$.tw. $f$ form passive. Another translation could be 'so that one will give to you protection ///.'

${ }^{20}$ Hannig, Ägyptisches Wörterbuch II, 2: 2795.
} 


\section{The Statue of Mery "the High Priest of Amun" \\ in the Egyptian Museum, Cairo CG 973}

\section{Textual Remarks}

F- The determinative used for writing ssnt is not clearly visible, but it should be the face sign (nose, eye and cheek: Gardiner, sign list D 19) ${ }^{21}$

G- The area following $k b h w$ is also severely damaged, but I agree with Borchardt's reconstruction which is irtt after the irp (to mean wine and milk). This is what could be expected in the lists of offering formulae. ${ }^{22}$

H- This line is particularly difficult because of the statue's severe damage. According to Borchardt, it reads di tw $n . k \quad s 3 \quad n \quad$ sn irt ib D 1108 , which seems unlikely to me. The $t$ sign, the three strokes, along with the heart sign that are following the eye sign, are not visible. At the beginning, I thought it could be read as šnt.sn, which means "their incantations ${ }^{\prime 23}$ as a plural noun, but this is difficult to figure out from the statue. More important, this transliteration does not work with our piece's meaning (that one will give you their incantations). Only traces of the eye sign can be detected. The possibility of reading the last part as irt-ib (to do the will of) is unlikely based on the current state of preservation. ${ }^{24}$

I- $s m r$ is considered a court title that represents a friend of the king. The main entry of $t k n$ is 'to be near or to approach.' Based on the WB, $h^{\top} w-n t r$ means 'the king's body. ${ }^{25}$ The Eighteenth Dynasty provides us with several parallels for the sentence smr tkn $m h^{\complement} w$-ntrr. ${ }^{26}$ The same line is mentioned in the tomb of Tjanuni TT 74: 'the friend who is close to the flesh of the god. ${ }^{27}$ In the Catalogue Général, Borchardt mistakenly wrote after $t k n$ the sign of $H r$, but this is not correct. ${ }^{28}$ The writing of $H r$ should be substituted with the owl $m$ to be $t k n m$, especially that we have some

\footnotetext{
${ }^{21}$ For ssn, see Hannig, Ägyptisches Wörterbuch II, 2: 2346.

${ }^{22}$ For a parallel, see W. Barta, Aufbau und Bedeutung der altägyptischen Opferformel, ÄgForsch 24 (Glückstadt-New York, 1968),110 (e).

${ }^{23}$ Hannig, Großes Handwörterbuch Ägyptisch-Deutsch, 893.

${ }^{24}$ For $i r i-i b$, see Hannig, Ägyptisches Wörterbuch II, 1: 158 (to fulfill the wish of).

${ }^{25}$ WB III, 39 (1-6).

${ }^{26}$ For tkn m, see Hannig, Ägyptisches Wörterbuch II, 2: 2708 and 1617-1619, esp. 1618 for $h^{\complement} w$-ntrw; WB V, 334 (c); A. Awadallah, Les Stèles privées à l'époque d'Aménophis III (Le Caire, 2008), 221-227, esp. 226, doc. 68.

${ }^{27}$ A. Brack and A. Brack, Das Grab des Tjanuni. Theben Nr. 74, AVDAIK19 (Mainz am Rhein, 1977), 37, 85.

${ }^{28}$ Borchardt, Statuen und Statuetten, 10.
} 
identical examples of this line in the tomb of Iamunedjeh. ${ }^{29}$ In addition, the sign after $\mathrm{Hr}$ is written mistakenly by Borchardt as rnpt sign and it should be substituted by $n \underline{t} r$ sign.

J- The main significance of st-wrt is 'the throne of the god or the king;' whereas in the beginning of the Eighteenth Dynasty, it was changed to mean 'the pedestal upon which was placed the sacred bark of the god during processions. ${ }^{30}$

\section{Comments}

\section{Additional Related Monuments}

Details about Mery's life, career and titles come from diverse sources, the most important being his tomb TT 95. There are two funerary cones (Nos. 390 and 400) that are attributed to Mery, both of which mention his titles. ${ }^{31}$ These funerary cones are currently displayed in the Petrie Museum in London (UC 37790 and 37791). ${ }^{32}$ In addition, Mery's name was found in the tomb of $D h w y$ (TT 45), the steward of Mery. ${ }^{33}$

The titles recorded on cone 390 are: (s $\underline{d} 3 w$ ty) bity; imy-r3 hmw-ntr $n w \check{s} m^{\top} w$ T3-mhw; hm-ntr tpy n'Imn; imy-r’ pr n'Imn; imy-r3 šnwty n 'Imn; imy-r’ prwy hd imy-r' prwy nbw n 'Imn; imy-r3 ihw $n$ 'Imn. While cone 400 adds more titles, which are: imy-r3 3 hwt n'Imn; himw nbt m pr nswt. ${ }^{34}$

${ }^{29}$ Urk IV, 959 (2, 9), 960 (1), 959 (7: for smr tkn m nb.f).

${ }^{30}$ For st-wrt, see P. Spencer, The Egyptian Temple: A Lexicographical Study (London-

Boston, 1984), 108-109; Hannig, Ägyptisches Wörterbuch II, 2: 2048: 'high throne (of the kings or gods).'

${ }^{31}$ For Mery's cones and titles, see G. Dibley and B. Lipkin, A Compendium of Egyptian Funerary Cones, with cone translations by J. Masquelier-Loorius (London, 2009), cones nos. 390, 400 (p. 129, 131, 249, 251); N. de Garis Davies, A Corpus of Inscribed Egyptian Funerary Cones. Part 1. Plates, M. F. Laming Macadam, ed. (Oxford, 1957), nos. 390, 400; W. Wreszinski, Die Hohenpriester des Amon (Berlin, 1904), §4; G. Lefebvre, Histoire des Grands Prêtres D'Amon de Karnak Jusqu'à la XXIe Dynastie (Paris, 1929), 91-93, 235-237; Urk. IV, 1414-1415, nos. 429-430.

${ }^{32}$ J. Kondo, "Inscribed Funerary Cones from Dra' Abu al-Naga," Orient 28 (1992), 111-123, esp. 114.

33 J. J. Shirley, The Culture of Officialdom: An Examination of the Acquisition of Offices during the Mid-18 th Dynasty, UMI Dissertation Services (Baltimore, 2005), 259.

${ }^{34}$ Al-Ayedi, Index, 453-454, no. 1566 (htmtw/y bity); 46, no. 155 (imy-r3 pr n'Imn); 128-129, no. 423 (imy-r3 šnwty n 'Imn); 28-29, no. 96 (imy-r3 prwy ḥd); 29-30, no. 98 (imy-r3 prwy had imy-r3 prwy nbw n'Imn); 14-16, no. 47 (imy-r3 ihw n Imn); 4, no. 12 (imy-r3 3hwt n 'Imn); 452-453, no. 1562 (htmw nb $m$ pr nsw). Other titles were not mentioned in the two cones such as hry-tp it ntr $n$ 'Imn 'chief god's father of Amun;' hry-tp, imy-r3 šm`w 'the chief, the overseer of Upper Egypt' and it-ntr $n$ st wrt 'god's father of the great throne.' For the latter title, see Al-Ayedi, Index, 182-183, no. 629. 


\section{The Statue of Mery "the High Priest of Amun" in the Egyptian Museum, Cairo CG 973}

The (seal-bearer) of the king of Lower Egypt; the overseer of the priests of Upper and Lower Egypt; the high priest of Amun; the steward of Amun; the overseer of the granaries of Amun; the overseer of the double treasury of silver and the double treasury of gold of Amun; the overseer of the cattle of Amun; the overseer of the fields of Amun; and the one who seals everything in the palace. ${ }^{35}$

Mery was the owner of TT 95 which is located in the middle of the cemetery of the early Eighteenth Dynasty officials in Thebes. ${ }^{36}$ TT 95 is in a bad state of preservation, and its decoration is unfinished. The tomb faced severe damages after being used by the Copts. ${ }^{37}$ As stated by several scholars, Mery also usurped tomb TT 84, which belonged to Iamunedjeh and his wife Henutnofret. This is based on a sequence of scenes in TT 84 where the name and the titles of Iamunedjeh and his wife were substituted by those of Mery and his mother. ${ }^{38}$ TT 84 was built during the reign of Thutmose III.

${ }^{35}$ For Mery's titles, see P. Der Manuelian, Studies in the Reign of Amenophis II, HÄB 26 (Hildesheim, 1987),106-107; C. H. Roehrig, The Eighteenth Dynasty Titles Royal Nurse (mn`t nswt), Royal Tutor (mn` nswt), and Foster Brother/Sister of the Lord of the Two Lands (sn/snt mn` $n n b t 3 w y)$, UMI Dissertation Services (Ann Arbor, 1990), 141-142; C. F. Aling, A Prosopographical Study of the Reigns of Thutmosis IV and Amenhotep III, UMI Dissertation Services (Ann Arbor, 1976), 116-119.

${ }^{36}$ For a description of the scenes of TT 95, see A. Gnirs et al., "Zweiter Vorbericht über die Aufnahme und Publikation von Gräbern der 18. Dynastie der Thebanischen Beamtennekropole," MDAIK 53 (1997), 57-83, esp. 64-66. For information on both tombs, see F. Kampp, Die Thebanische Nekropole: Zum Wandel des Grabgedankens von der XVIII. bis zur XX. Dynastie, Theben 13, vol.1 (Mainz am Rhein, 1996), TT 95 (pp. 358-360), TT. 84 (pp. 332-336); M. Wasmuth, Innovationen und Extravaganzen: Ein Beitrag zur Architektur der Thebanischen Beamtengräber der 18. Dynastie, BAR-IS 1165 (Oxford, 2003), TT 95 (pp. 107-108), TT 84 (pp. 102-103); Urk. IV, 1570-1571 (TT 95); Urk. IV, 937-962 (TT 84).

${ }^{37}$ M. Underwood and H. Behlmer, "Coptic Documents from the Tomb of Mery, Theban Tomb No. 95," in P. Buzi et al., Coptic Society, Literature and Religion from Late Antiquity to Modern Times. Proceedings of the Tenth International Congress of Coptic Studies, Rome, September $17^{\text {th }}-22^{\text {th }}$ and Plenary Reports of the Ninth International Congress of Coptic Studies, Cairo, September $15^{\text {th }}-19^{\text {th }}$ 2008, OLA 247, vol.1 (Leuven, 2016), 779-793.

38 Gnirs et al., "Zweiter Vorbericht über die Aufnahme und Publikation," 58-59; B. M. Bryan, "Administration in the Reign of Thutmose III," in E. H. Cline and D. O'Connor, eds., Thutmose III: A New Biography (Ann Arbor, 2006), 69-122, esp. 84, 89-90; J. J. Shirley, "One Tomb, Two Owners: Theban Tomb 122-Re-Use or Planned Family Tomb?" in Z. Hawass and J. H. Wegner, eds., Millions of Jubilees: Studies in Honor of David P. Silverman, CASAE 39, vol. 2 (Cairo, 2010), 271-301, esp. 298-299, footnote 85. 
Mery was the high priest of Amun who served under the reign of Amenhotep II. His father Nebpehtire was 'a high priest of Min at Koptos' hm-ntr tpy $n$ $M n w G b t y w^{39}$ and his mother Hunay was 'a great royal nurse of the lord of the two lands' $m n^{\top} t$ wrt $n n b t 3 w y .{ }^{40}$ The position of his father is inferior in its power and ranking compared to that of Mery. On the other hand, Hunay played a crucial role in both the life and career of her son. She seemed to be the intermediary for his accession to his position. ${ }^{41}$ It was normal during the Eighteenth Dynasty for the elite women, such as royal nurses, to possess affectionate relationships with the royal family. ${ }^{42}$ These prominent positions provide advantages to the women's families. Such mothers seldom have private monuments for themselves, but in most of the cases, they are memorialized with their husbands or sons as the case of Hunay here. ${ }^{43}$ As mentioned by Roehrig, it seems that Mery obtained this high position through his mother and not his father. ${ }^{44} \mathrm{He}$ did not pass through the same stages attained by other high priests in his ranking, such as Menkheperresenb who preceded him. ${ }^{45}$ The best proof of the importance of Hunay is the fact that she is mentioned several times in the tomb of her son (at least three times), as well as in TT 84, compared to his wife Diy, who is only mentioned once in his original tomb TT $95 .{ }^{46}$

The exact relationship between Mery and Iamunedjeh remains obscure. ${ }^{47}$ According to some scholars, Mery accredited his promotion to Iamunedjeh,

39 Roehrig, The Eighteenth Dynasty Titles Royal Nurse, 137, 347; S. S. Eichler, Die Verwaltung des «Hauses des Amun» in der 18. Dynastie, SAK 7 (Hamburg, 2000), 281, no. 268. For the name of Nebpehtire, see Ranke, PN II, 296, no. 20.

${ }^{40}$ For a list of the titles of Hunay, see Roehrig, The Eighteenth Dynasty Titles Royal Nurse, 142-143; Shirley, The Culture of Officialdom, 261-262.

${ }^{41}$ According to Roehrig, there is no information about the lineage of Mery's parents (Roehrig, The Eighteenth Dynasty Titles Royal Nurse, 137, 142).

${ }^{42}$ G. Robins, Reflections of Women in the New Kingdom: Ancient Egyptian Art from The British Museum. An Exhibition Organized by the Michael C. Carlos Museum, Emory University, February 4 - May 14, 1995 (San Antonio, 1995), 40.

${ }^{43}$ Robins, Reflections of Women in the New Kingdom, 40.

${ }^{44}$ Roehrig, The Eighteenth Dynasty Titles Royal Nurse, 142.

${ }^{45}$ Roehrig, The Eighteenth Dynasty Titles Royal Nurse, 142.

${ }^{46}$ Gnirs et al., "Zweiter Vorbericht über die Aufnahme und Publikation," 65-68; Roehrig, The Eighteenth Dynasty Titles Royal Nurse, 137-138; Shirley, The Culture of Officialdom, 261. For Mery's wife, see Urk. 1571 (16): snt.f nbt pr Diy m3`t-hrw.

${ }^{47}$ B. Bohleke, The Overseers of Double Granaries of Upper and Lower Egypt in the Egyptian New Kingdom, 1570-1085 B.C, UMI Dissertation Services (Ann Arbor, 1991), 7999 (for a discussion of Iamunedjeh and his family). For a discussion of the bloc statue of Iamunedjeh in the Egyptian Museum at Cairo, see W. C. Hayes, "A Statue of the 


\section{The Statue of Mery "the High Priest of Amun" in the Egyptian Museum, Cairo CG 973}

so he usurped Iamunedjeh's tomb 10-20 years after his death because he had no sons or subordinates to take care of his funerary rituals. According to the interpretations proposed by Polz ${ }^{48}$ Mery did not seize the tomb, but rather transferred it to his belongings in order to perform the funerary rituals for Iamunedjeh who did not have sons. ${ }^{49}$

\section{Mery's Duties and Titles}

As mentioned by Lefebvre, Mery's titles, which are more than ten, can be divided into three categories: religious, civil, or those related to the domain of Amun. ${ }^{50}$ Based on the preponderance of these epithets, I am only going to discuss a few of them.

It is obvious that the majority of Mery's titles are linked to Amun. The influence and power that the high priest of Amun enjoyed during this period can be proved by the growth of their titles as was the case of Mery. ${ }^{51}$ Mery received this honor of high priest of Amun only during the reign of Amenhotep II, the only king attested on Mery's monuments. ${ }^{52}$

The high priest of Amun hm-ntr tpy $n$ 'Imn was usually chosen by the king. The king awarded priesthood to persons that he wanted to compensate. ${ }^{53}$ It was a long-lasting position, not like that of the vizier. The high priest career

Herald Yamu-Nedjeh in the Egyptian Museum, Cairo, and Some Biographical Notes on Its Owner," ASAE 33 (1933), 6-16 (with 1 plate), esp. 10-11; Urk. IV, 1370, no. 409; W. W. Helck, Zur Verwaltung des Mittleren und Neuen Reichs, Pdت̈ 3 (Leiden, 1958), 384-386, 496, no. 3.

${ }^{48}$ D. Polz, "Jamuenedjeh, Meri und Userhat," MDAIK 47 (1991), 281-291, esp. 290-291.

49 For information about the first royal herald 'T3mw- $n d h$, see Gnirs et al., "Zweiter Vorbericht über die Aufnahme und Publikation," 58-60; D. Raue, Heliopolis und das Haus des Re. Eine Prosopographie und ein Toponym im Neuen Reich, ADAA 16 (Berlin, 1999),147-148; J. J. Shirley, "What's in a Title? Military and Civil Officials in the Egyptian 18th Dynasty Military Sphere," in S. Bar et al., eds., Egypt, Canaan and Israel: History, Imperialism, Ideology and Literature. Proceedings of a Conference at the University of Haifa, 3-7 May 2009, CHANE 52 (Leiden-Boston, 2011), 291-319, esp. 306308.

${ }^{50}$ Lefebvre, Histoire des Grands Prêtres D’Amon, 237.

${ }^{51}$ Aling, A Prosopographical Study, 114; B. Haring, "The Rising Power of the House of Amun in the New Kingdom," in M. García and J. Carlos, eds., Ancient Egyptian Administration, HdO 104 (Leiden, 2013), 607-637, esp. 622.

${ }^{52}$ See Urk. IV, 1570 (16), no. 511.

${ }^{53}$ B. E. Shafer, "Temples, Priests, and Rituals: An Overview," in D. Arnold et al., Temples of Ancient Egypt, B. E. Shafer, ed., (New York, 1997), 1-30, esp. 9; E. Teeter, Religion and Ritual in Ancient Egypt (Cambridge, 2011), 26-27. 
did not end by the death of a specific pharaoh like other positions. ${ }^{54}$ So one priest could serve under the reigns of more than one king.

Some of the secondary titles of Mery are related to the administration of the temple estates'-such as cattle, fields, two houses of gold and silver, and others. There is no doubt that he enjoyed important positions connected with the administration of the domain of Amun, but the job of the high priest of Amun was his last occupation. ${ }^{55}$

The title imy-r3 hmmw-ntr nw šm ${ }^{\complement} w T 3-m h w$, 'the overseer of all the priests of Upper and Lower Egypt,' was concerned with supervising all the priestly officials throughout Egypt. ${ }^{56}$ Most likely the bearer of this title possessed some administrative duties related to the nomination of priests of all deities of Egypt, the division of the financial resources of local temples, as well as the allocation of offerings to all the temples of Egypt. ${ }^{57}$

The title imy-r' ihw $n$ 'Imn, 'the overseer of the cattle of Amun,' is a very popular title in the Eighteenth Dynasty. ${ }^{58}$ It appears that Mery was the last high priest to take possession of the title overseer of the cattle of Amun. ${ }^{59}$ This title was not granted to any high priest of Amun after Mery.

As mentioned by Eichler, during the reign of Thutmose III, the management of the temple treasury was usually placed in the hands of the high priest of the temple of Amun. ${ }^{60}$ That is why the three high priests, Menkheperresenb II, Amenemhat and Mery, all bore the title 'overseer of the treasuries.' Starting from Mery's time, the treasury of the temple became a separate administrative entity, away from the civil sphere. Mery was the first bearer of the title imy-r3 prwy ha nbw n'Imn 'the overseer of the double treasury of silver and gold of Amun, ${ }^{61}$ and from then onwards this title was in use.

\footnotetext{
${ }^{54}$ Aling, A Prosopographical Study, 115. Later on the New Kingdom, the position of the high priest usually took place through heritage or a divine oracle instead of the king's selection (Shafer, "Temples, Priests, and Rituals," 13).

${ }^{55}$ Polz, "Jamuenedjeh, Meri und Userhat," 284.

56 For a list of all the holders of this title in the Eighteenth Dynasty, see Aling, $A$ Prosopographical Study, 245-246.

${ }^{57}$ Aling, A Prosopographical Study, 245.

${ }^{58}$ For a list of the bearers of this title, see Aling, A Prosopographical Study, 236-237. According to Aling, there is a possibility of having more holders because of the title prevalence.

${ }^{59}$ Aling, A Prosopographical Study, 243.

${ }^{60}$ Eichler, Die Verwaltung des «Hauses des Amun», 121,123-126, 224.

${ }^{61}$ Eichler, Die Verwaltung des «Hauses des Amun», 121; Haring, "The Rising Power of the House of Amun," 620.
} 


\section{The Statue of Mery "the High Priest of Amun" \\ in the Egyptian Museum, Cairo CG 973}

The imy-r' $\mathrm{pr} n$ 'Imn, 'the chief steward of the temple of Amun' was another title related to the economic influence of the temple of Amun. Judging by the small number of the bearers of this title, it seems that only one person holds this title at a time. ${ }^{62}$ The holder of this title is responsible for overseeing and superintending the properties and estates of Amun. As mentioned by Aling, during the reign of Amenhotep II, there were three persons carrying this title: Mery, Amenemhat (both of them were high priests of Amun) and Senefer (the mayor of Thebes). ${ }^{63}$ This shift of supervising the holdings of Amun from the governors to the high priests indicates the authority that the high priest of Amun enjoyed. This apogee reached its peak during the period of Mery who carried out the three-fundamental administrative and religious positions, which are overseer of cattle of Amun, overseer of all priests, and steward of the temple estates. ${ }^{64}$

\section{Conclusions}

This paper sheds light on an important statue and challenging inscriptions belonging to one of the well-known royal officials in the Eighteenth Dynasty. Even though the piece is damaged, it is crucial to analyze the titles and epithets of one of the distinctive high priests of Amun, who lived during the reign of Amenhotep II. CG 973 demonstrates how the post of the high priest of Amun at Karnak became specifically independent and dominant. As can be seen, he attained almost all the positions related to the administration of estates of Amun, in addition to his religious and civil posts. Moreover, the statue highlights the prestige of royal nurses during this period of time.

Even though nothing is recorded about the statue's provenance, I believe that it originates from Thebes, most likely from the Karnak temple, based on the position of Mery.

\footnotetext{
62 Aling, A Prosopographical Study, 251-252.

${ }^{63}$ Aling, A Prosopographical Study, 254-255; Eichler, Die Verwaltung des «Hauses des Amun», 224.

${ }^{64}$ Aling, A Prosopographical Study, 255; Haring, "The Rising Power of the House of Amun," 622.
} 

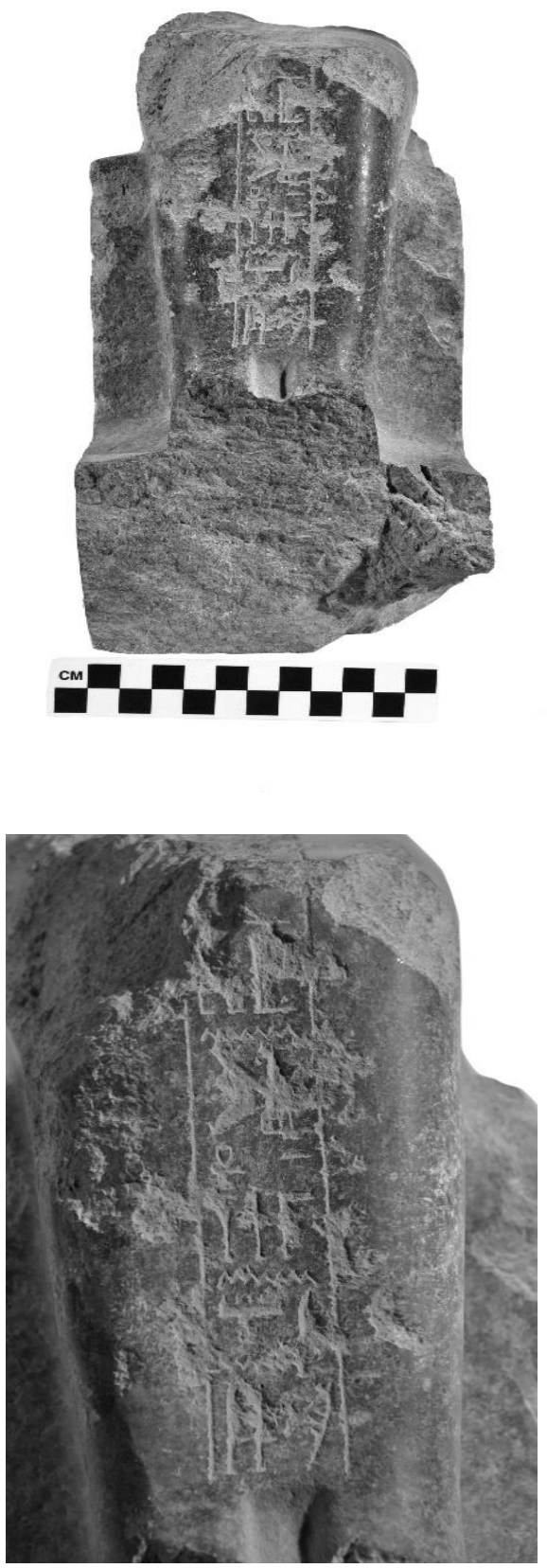

Fig. 1: Front view of the statue of Mery (Photograph courtesy of the Cairo Museum)
Fig. 2: Inscriptions down the kilt of Mery (Photograph courtesy of the Cairo Museum) 
Fig. 3: Facsimile of the inscriptions on the kilt of Mery (Illustration by Mohamed Osman)

Fig. 4: Facsimile of the inscriptions on the kilt of Mery (Illustration by Mohamed Osman)
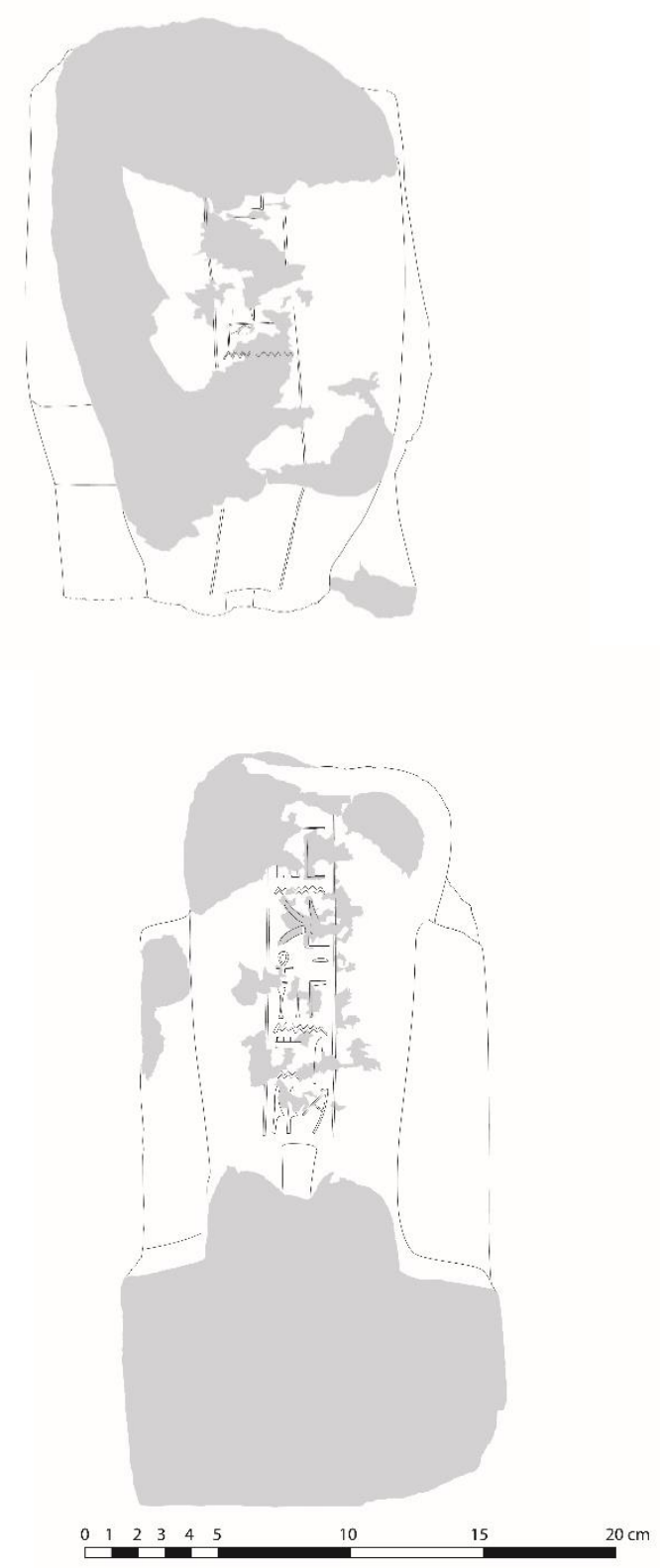


\section{Dina El Gabry}

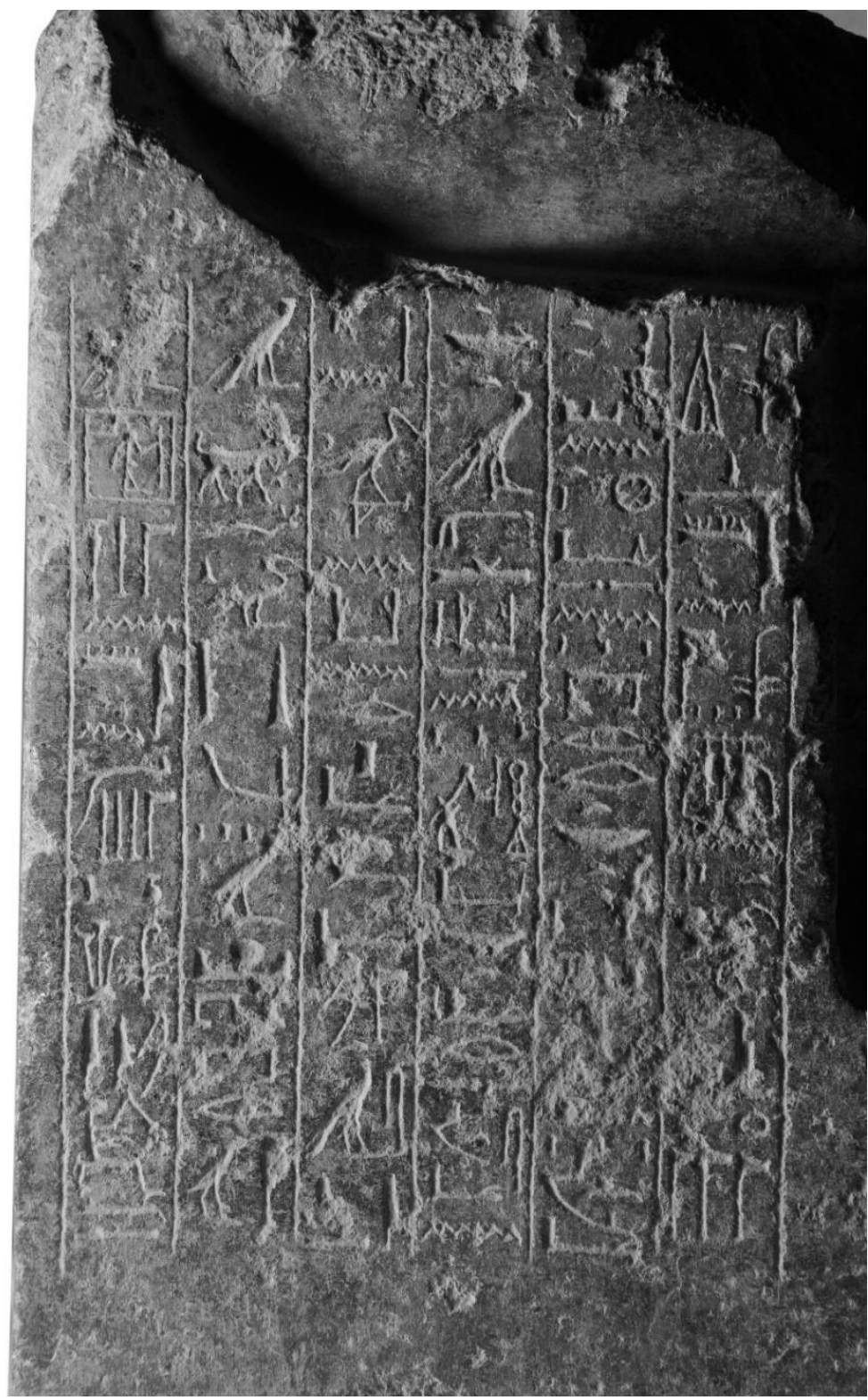

Fig. 5: Right side of the seat

(Photograph courtesy of the Cairo Museum) 


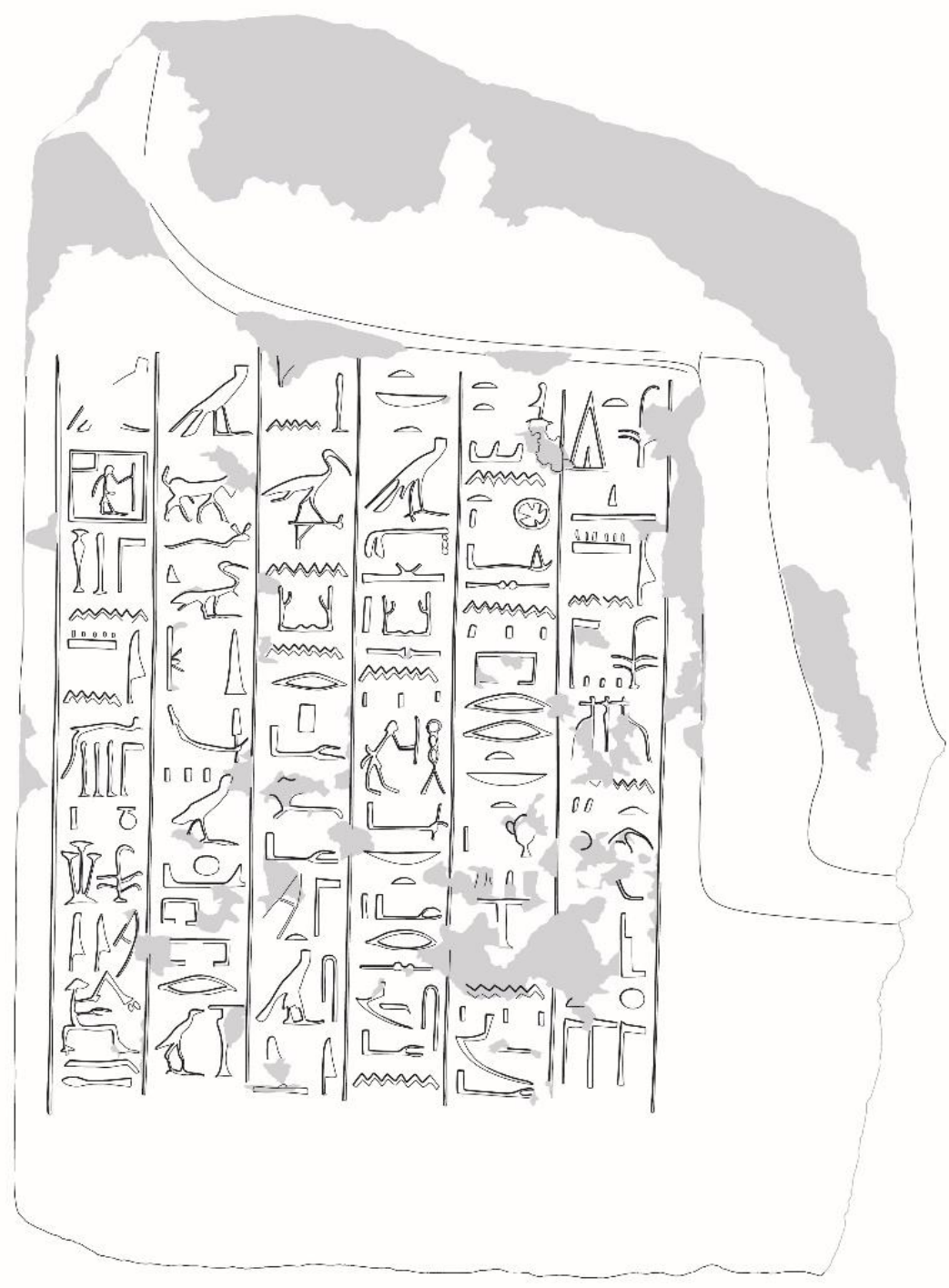

Fig. 6: Facsimile of the right side of the seat (Illustration by Mohamed Osman) 


\section{Dina El Gabry}

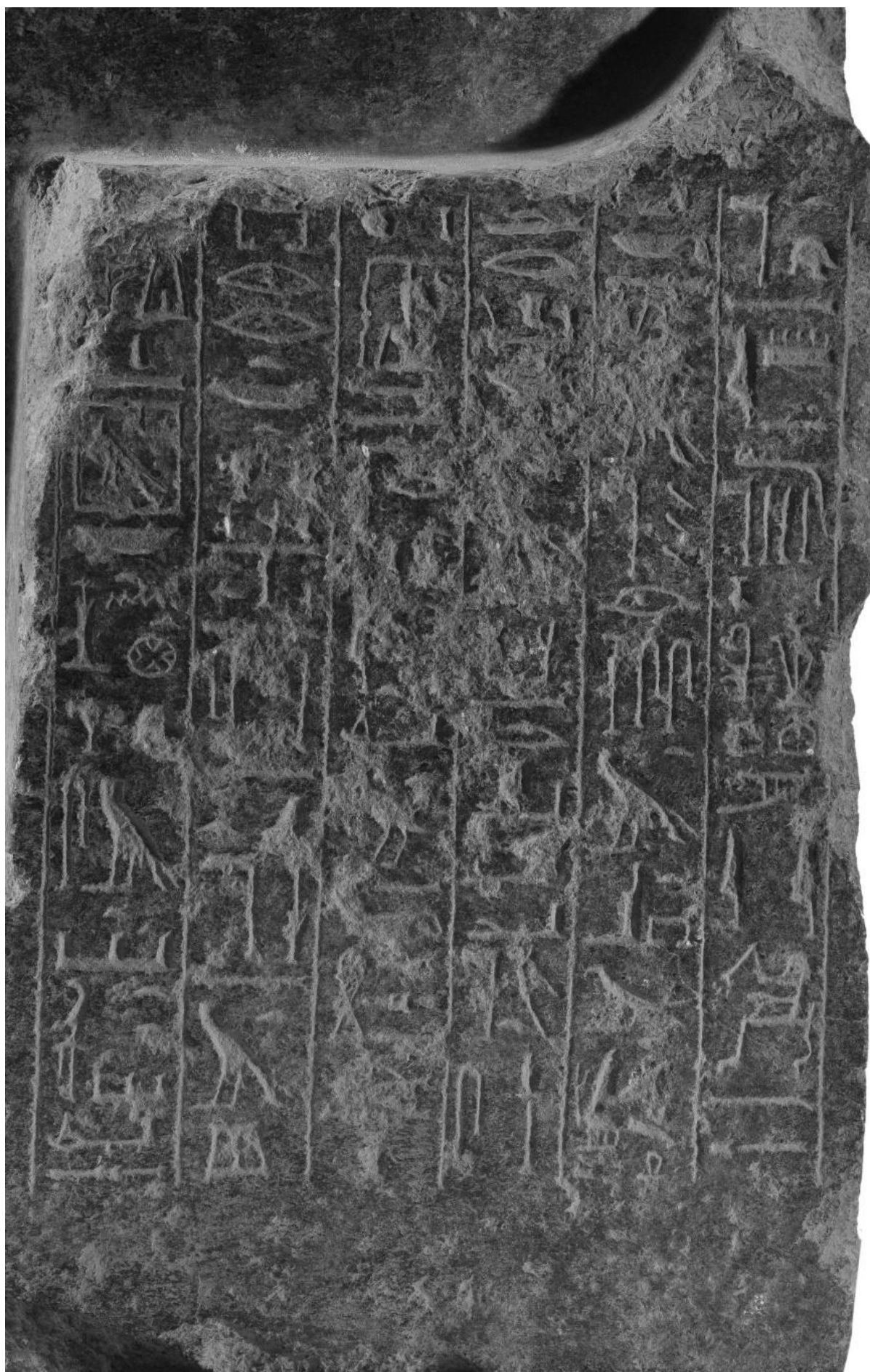

Fig. 7: Left side of the seat (Photograph courtesy of the Cairo Museum) 


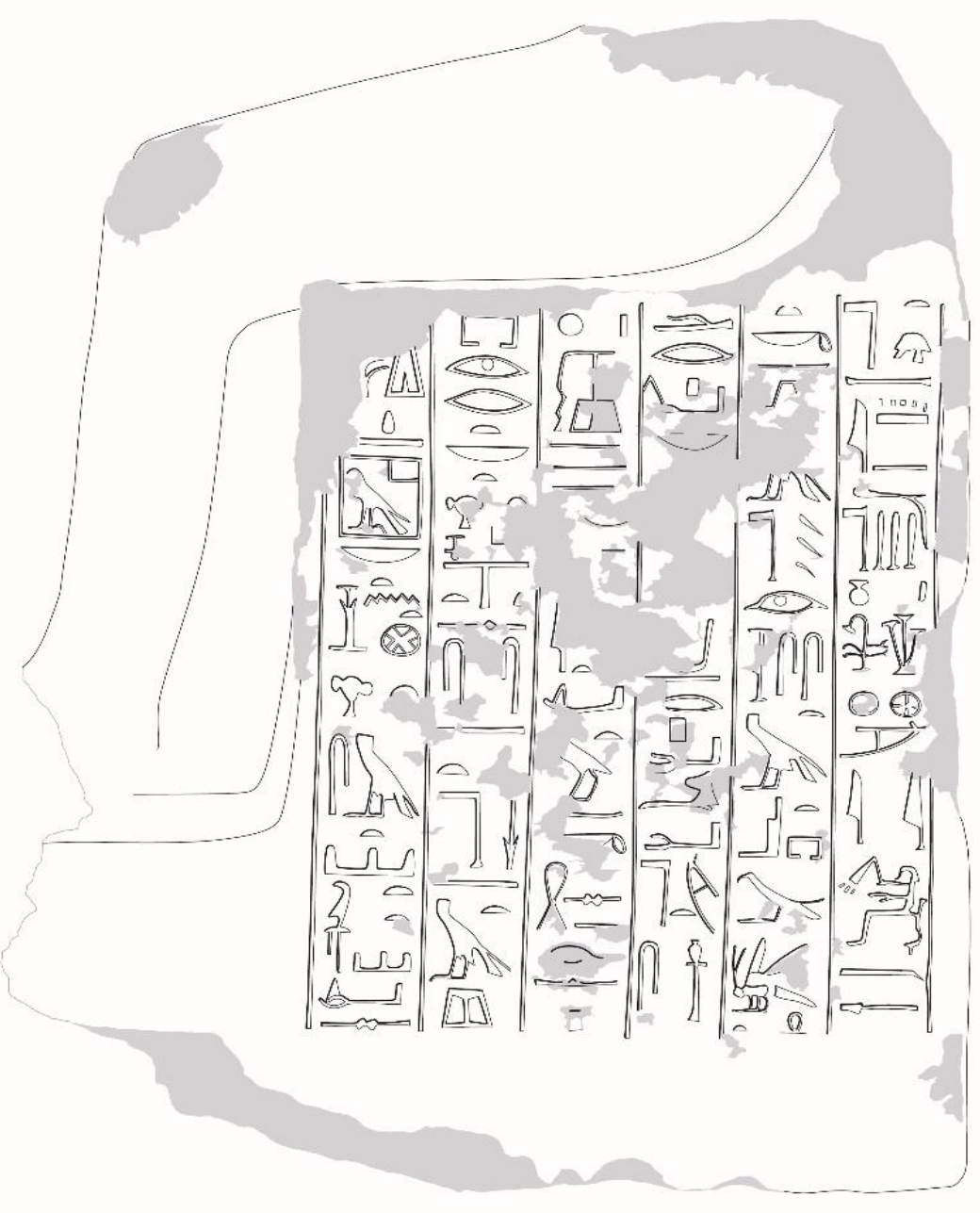

Fig. 8: Facsimile of the left side of the seat (Illustration by Mohamed Osman) 